\title{
Influence of experience on intake and feeding behavior of dairy sheep when offered forages from woody plants in a multiple-choice situation ${ }^{1}$
}

\author{
J. S. Meier,* A. Liesegang, $\dagger$ B. Rischkowsky, $\$$ M. Louhaichi, \\ M. Kreuzer,* and S. Marquardt*2
}

\begin{abstract}
*ETH Zurich, Institute of Agricultural Sciences, Universitaetstrasse 2, 8092 Zurich, Switzerland; †University of Zurich, Institute of Animal Nutrition, Winterthurerstrasse 260, 8057 Zurich, Switzerland; and \$ICARDA, Tel Hadya, Aleppo, Syria
\end{abstract}

ABSTRACT: A satisfactory intake of novel lowquality forages by ruminants may require previous experience with this feed. Therefore, this study tested in sheep whether experience with forages from woody plants had an influence on feed intake, feeding behavior, and nutrient supply when offered in a multiple-choice arrangement. Two sheep experiments were conducted, 1 in Syria (Mediterranean region; Exp. 1) and the other in Switzerland (Central Europe; Exp. 2), that investigated 5 and 6 woody test plants, respectively. In Exp. 1, the test plants were Artemisia herba-alba, Atriplex leucoclada, Haloxylon articulatum, Noaea mucronata, and Salsola vermiculata. In Exp. 2, Betula pendula, Castanea sativa, and Juglans regia were used in addition to $A$. leucoclada, $H$. articulatum, and $S$. vermiculata (the plants most consumed in Exp. 1). In each experiment, 12 lactating sheep (Awassi sheep in Exp. 1 and East Friesian Milk sheep in Exp. 2) were allocated to 2 groups ("experienced" and "naïve"). Experienced sheep subsequently were familiarized with each test plant during a learning period of binary choices (1 test plant vs. barley straw) for $4 \mathrm{~h}$ in the morning for $7 \mathrm{~d}$ each. The naïve group received only straw. During the rest of the day, a basal diet composed of barley straw (ad libitum) and concentrate was offered to both groups. For the 2 wk following the learning period, the sheep were subjected to feeding of the basal diet to avoid carryover effects of the last offered test plant. In the following multiple-choice period, both groups were allowed to select from all test plants during $4 \mathrm{~h}$ in the morning for $14 \mathrm{~d}$. Forage intake after 4 and 24 $\mathrm{h}$ and feeding behavior during the first $30 \mathrm{~min}$ of the test feeding were assessed. Milk yield and composition were measured at the end of the multiple-choice period. Nutrient intake was calculated using feed intake measurements and compositional analyses. Only in Exp. 2 , group differences $(P<0.05)$ were found on $\mathrm{d} 1$ of the multiple-choice period. The experienced sheep consumed more total forage, straw, OM, NDF, ADF, and ADL (nutrients without concentrate). However, across the entire multiple-choice period, there were no differences $(P \geq 0.05)$ in forage and nutrient intake, feeding behavior, and milk yield and composition between the groups in both experiments. This suggests that sheep can quickly adapt to previously unknown woody feeds of varying origin and quality offered as dried supplements.

Key words: dairy sheep, experience, feed choice, feeding behavior, intake, woody plants

(C) 2013 American Society of Animal Science. All rights reserved.

J. Anim. Sci. 2013.91:4875-4886 doi:10.2527/jas2012-5923

\section{INTRODUCTION}

In arid and semiarid areas, woody plants are often used as supplements to provide extra protein, which is low in poor-quality forages (Leng, 1997). To cope with

\footnotetext{
${ }^{1}$ Funded in part by the North-South Center, ETH Zurich. The authors are grateful for the assistance by the laboratory staff at ICARDA and ETH Zurich and help provided during the experiments by the animal caretakers at the University of Zurich and ICARDA.

${ }^{2}$ Corresponding author: svenja.marquardt@usys.ethz.ch

Received October 1, 2012.

Accepted July 28, 2013.
}

the general feed scarcity during dry periods, farmers could collect parts of the plants when plenty of material is available and feed this material to animals in dried form. Moreover, when animals are able to select their diet from a wide range of plant species, they could compose their diet based on complementarity of nutrients and energy (Duncan et al., 2003) and avoidance of toxins. In addition, animals that have experience with woody plants may ingest more of such feeds given as supplements, including those that contain certain levels of plant secondary metabolites (Villalba et al., 2004). In 
contrast, inexperienced animals are expected to be more reluctant to eat unknown feeds; this is also related to neophobia (Provenza and Balph, 1988). This reluctance happens particularly when feeds are not highly palatable. Therefore, animals need to learn what to ingest and to what level (or how much to consume). Therefore, experience should be advantageous to promote fast acceptance and higher intake of novel feeds (Catanese et al., 2012).

The present study tested the following hypotheses: 1) experience with woody forages leads to a higher total forage and nutrient intake when several woody forages are offered in a multiple-choice situation and 2) this experience affects feeding behavior. These hypotheses were tested in choice feeding experiments using woody plants characteristic of 2 contrasting regions. These plants differed in nutrient composition and plant secondary metabolites and were offered as dried supplements. The 2 hypotheses were tested in 2 countries with 2 dairy sheep breeds.

\section{MATERIALS AND METHODS}

\section{Study Regions and Experimental Feeds}

The experiment in Switzerland was approved by the Cantonal Veterinary Office of Zurich. The treatment of the animals in Syria, where no such approval procedures are established, was the same.

The present study involved the Mediterranean region (a warm and dry climate) and the Central European region (a temperate and more humid climate) with the regions' special feeds and livestock breeds. In each study region, 1 dairy sheep experiment was conducted. Experiment 1 was performed in Syria, which was chosen as a representative area of the Mediterranean region. Experiment 2 was performed in Switzerland, an area representative of Central Europe. In both regions, forages from typically available woody plants were used (Table 1). In Syria, dried leaves and fine twigs were collected from the following steppe shrubs: Artemisia herba-alba (from Al-hammam), Atriplex leucoclada (from Maskana), Haloxylon articulatum (from Wadi Al-azib), Noaea mucronata (from Hazm Al-sur), and Salsola vermiculata (from Abisan and Drehim). Each plant species was sampled from several individual plants over several weeks in March and April 2010, after the early spring rainy season when the plants were sprouting. After the plants were collected, they were completely dried in the shade underneath a roof for 2 to $5 \mathrm{~d}$. The duration depended on plant species and ambient temperatures ranging from 8 to $26^{\circ} \mathrm{C}$. The material was then pooled per plant species across sampling days to ascertain an equal distribution of the batches to avoid variations in nutritional composition. The plant material was stored in jute bags until it was distributed to the sheep. In Exp. 1, the test plants were not chopped before they were fed to the sheep. As representative woody forages of the Central European region (Exp. 2), dried and chopped (particle size: maximum $1 \mathrm{~cm}$ ) leaves of 3 tree species, Betula pendula (from Albania), Castanea sativa (from Albania), and Juglans regia (from Bulgaria), were purchased from Alfred Galke GmbH, Gittelde, Germany. The 3 plant species that had been consumed the most in Exp. 1 (A. leucoclada, $H$. articulatum, and $S$. vermiculata) were also tested in Exp. 2. These 3 forages were also chopped to about $1 \mathrm{~cm}$ (leaves), and twigs were cut to maximum $3 \mathrm{~cm}$ long to achieve a similar physical structure across the test plants. Experiment 1 was conducted at the International Center for Agricultural Research in the Dry Areas (ICARDA), Aleppo, Syria, in June 2010 (early summer). Experiment 2 was performed in August 2011 (late summer) at the Institute of Animal Nutrition, University of Zurich, Zurich, Switzerland. In Syria, the temperature and humidity during the experiment were $26^{\circ} \mathrm{C}$ and $49 \%$ on average. In Switzerland, average temperature and humidity was $23^{\circ} \mathrm{C}$ and $67 \%$, respectively.

\section{Animals and Basal Diet}

Twelve adult lactating sheep in their 9th to 11th week of lactation were used in barn experiments. In Exp. 1, fat-tailed Awassi sheep were used. Sheep were weighed before morning feeding time but without previous feed or water restriction. The sheep had been grazed on pasture mainly composed of Avena barbata and Carex stenophylla and additionally fed ad libitum with silage composed of vetch and oat together with $1 \mathrm{~kg} / \mathrm{d}$ of concentrate (per kilogram: $500 \mathrm{~g}$ barley grain, $300 \mathrm{~g}$ wheat bran, $180 \mathrm{~g}$ cottonseed cake, $6 \mathrm{~g} \mathrm{NaCl}, 12 \mathrm{~g} \mathrm{CaHPO}_{4}$, and $2 \mathrm{~g}$ vitamin mixture) during milking. In Exp. 2, East Friesian Milk sheep were used that had been previously kept indoors and fed $1.2 \mathrm{~kg} / \mathrm{d}$ of a hay harvested in a young vegetation stage from a mixed sward of grass, legume and herb species and $0.5 \mathrm{~kg} / \mathrm{d}$ of a commercial concentrate including a vitamin-mineral mix and being designed for sheep (Combifloc 2921; Meliofeed, Herzogenbuchsee, Switzerland). The animals of Exp. 2 had previous experience in grazing on pasture but had never consumed woody forages.

During the experiments, the sheep received a basal diet composed of barley straw fed ad libitum and concentrate in amounts of on average 1.1 and $0.7 \mathrm{~kg} \cdot \mathrm{head}^{-1} \cdot \mathrm{d}^{-1}$ in Exp. 1 and 2, respectively, following the respective local practice for supplementing dairy sheep. When related to feeding recommendations (AFRC, 1993), these concentrate allowances were calculated to be large enough to ensure that the energy and protein requirements for maintenance and milk production were covered thus avoiding bias in test plant selection behavior. The con- 
Table 1. Chemical composition of the experimental feeds $(\% \text { of DM })^{1}$

\begin{tabular}{|c|c|c|c|c|c|c|c|c|c|c|c|c|c|c|}
\hline Feed & Plant family & Experiment & $n^{2}$ & $\mathrm{DM}^{3}$ & $\mathrm{OM}$ & NDF & $\mathrm{ADF}$ & $\mathrm{ADL}$ & $\begin{array}{c}\text { Non-NDF } \\
\text { CHO }\end{array}$ & $\mathrm{CP}$ & $\mathrm{EE}$ & $\mathrm{TP}^{4}$ & $\mathrm{TT}^{4}$ & $\mathrm{CT}^{5}$ \\
\hline \multicolumn{15}{|c|}{ Mediterranean shrub leaves and fine twigs } \\
\hline Artemisia herba-alba & Asteraceae & 1 & 9 & 92.9 & 83.2 & 42.0 & 34.8 & 10.5 & 24.1 & 12.5 & 2.19 & 2.45 & 1.59 & 0.01 \\
\hline Atriplex leucoclada & Chenopodiaceae & $1 / 2$ & $7 / 4$ & 91.4 & 80.3 & 42.7 & 25.6 & 6.5 & 17.5 & 18.2 & 1.25 & 0.68 & 0.42 & 0.01 \\
\hline Haloxylon articulatum & Chenopodiaceae & $1 / 2$ & $8 / 4$ & 92.7 & 83.7 & 45.8 & 27.2 & 6.9 & 16.6 & 18.0 & 0.97 & 2.29 & 1.32 & 0.03 \\
\hline Noaea mucronata & Chenopodiaceae & 1 & 8 & 93.1 & 87.3 & 65.9 & 45.3 & 12.4 & 12.2 & 8.0 & 0.67 & 0.55 & 0.28 & 0.01 \\
\hline Betula pendula & Betulaceae & 2 & 4 & 91.6 & 95.2 & 49.4 & 29.5 & 19.3 & 22.6 & 15.5 & 4.53 & 3.04 & 2.40 & 1.83 \\
\hline Castanea sativa & Fagaceae & 2 & 4 & 91.7 & 94.7 & 43.1 & 27.2 & 11.3 & 28.7 & 12.0 & 6.26 & 4.70 & 4.10 & 0.49 \\
\hline Juglans regia & Juglandaceae & 2 & 4 & 90.8 & 88.1 & 47.7 & 34.5 & 16.1 & 20.1 & 13.7 & 3.26 & 3.44 & 2.83 & 1.21 \\
\hline \multicolumn{15}{|l|}{ Barley straw } \\
\hline & & 1 & 9 & 93.2 & 86.9 & 66.9 & 41.7 & 4.2 & 13.9 & 5.4 & 1.20 & 0.77 & 0.43 & 0.01 \\
\hline & & 2 & 3 & 90.3 & 91.2 & 22.0 & 8.1 & 3.3 & 37.0 & 27.7 & 4.14 & 0.37 & 0.14 & 0.02 \\
\hline
\end{tabular}

${ }^{1} \mathrm{EE}$, ether extract; non-NDF CHO, non-NDF carbohydrates, calculated as OM - NDF - CP - EE - TP; TP, total phenols; TT, total tannins; CT, condensed tannins.

${ }^{2} n$, number of feed samples analyzed; $n=4$ for TP, TT, and CT.

${ }^{3}$ Percent of original substance.

${ }^{4}$ Given as gallic acid equivalents.

${ }^{5}$ Given as leucocyanidin equivalents.

centrate used in Exp. 1 consisted of barley (88.2\%), soybean meal (9.8\%), $\mathrm{CaHPO}_{4}(1.2 \%), \mathrm{NaCl}(0.6 \%)$, and a vitamin-mineral premix $(0.2 \%)$. The latter provided the following nutrients per kilogram of concentrate: $270 \mathrm{mg}$ Ca, $243 \mathrm{mg} \mathrm{Na}, 212 \mathrm{mg} \mathrm{P}, 1.52 \mathrm{mg} \mathrm{Mn}, 0.30 \mathrm{mg} \mathrm{Mg}$, $0.23 \mathrm{mg} \mathrm{Co}, 0.15 \mathrm{mg} \mathrm{I}, 24,500 \mathrm{IU}$ vitamin A, $600 \mathrm{IU}$ vitamin $\mathrm{D}_{3}$, and $1 \mathrm{mg}$ vitamin E. In Exp. 2, the concentrate (Combifloc 2957C; Melior AG, Herzogenbuchsee, Switzerland) consisted of wheat, barley, wheat starch, wheat and corn flakes, various mill byproducts, distiller's grains, soybean meal, maize gluten, canola expeller, sugarbeet pulp and molasses, vegetable oil, and a mineral-vitamin premix. The premix provided the following nutrients per kilogram of concentrate: $11 \mathrm{~g} \mathrm{Ca}, 5.5 \mathrm{~g} \mathrm{P}$, $3 \mathrm{~g} \mathrm{Mg}, 25,000 \mathrm{IU}$ vitamin A, 5,000 IU/kg vitamin $\mathrm{D}_{3}$, and $25 \mathrm{mg}$ vitamin $\mathrm{E}$. Via the concentrate, the animals in Exp. 2 were supplemented with $\mathrm{NaHCO}_{3}(20 \mathrm{~g} / \mathrm{d})$ and had ad libitum access to mineral licks (AgroLine AG, Roggwil, Switzerland) that provided the following nutrients per kilogram: $375 \mathrm{~g} \mathrm{Na}, 8 \mathrm{~g} \mathrm{Mg}, 800 \mathrm{mg} \mathrm{Zn,} 80$ mg Mn, $100 \mathrm{mg} \mathrm{I}, 30 \mathrm{mg} \mathrm{Se}$, and $30 \mathrm{mg}$ Co. In both experiments, the concentrate was always completely consumed, and access to fresh water was unrestricted.

\section{Experimental Design}

For both experiments, the same experimental design was applied and the aspects relevant for designing "choice" experiments were considered (Meier et al.,
2012). Before the experiments began, the animals were adapted for $7 \mathrm{~d}$ to their individual pens ( 2 by $2 \mathrm{~m}$ and 1.2 by $2 \mathrm{~m}$ in Exp. 1 and Exp. 2, respectively) and the feeding management $[4 \mathrm{~h}$ of test feeding in the morning (straw only) followed by feeding of the basal diet for the rest of the day; "adaptation period"; Fig. 1].

In each experiment, half of the ewes were allocated to 1 of 2 treatment groups. Group allocation was done in a way that groups were balanced for BW (Exp. 1, $62 \pm$ 9.0 and $59 \pm 7.7 \mathrm{~kg}$; Exp. 2, $61 \pm 10.7$ and $68 \pm 14.8 \mathrm{~kg}$; means \pm SD) and milk yield (Exp. 1, $912 \pm 154.3$ and $869 \pm 111.5 \mathrm{~g} / \mathrm{d}$, Exp. 2: $616 \pm 244.6$ and $972 \pm 418.5$ $\mathrm{g} / \mathrm{d}$ ). The first treatment group (experienced) underwent a learning period before the choice feeding situation was implemented (named the "multiple-choice period"). During the learning period, the experienced animals were familiarized with all test plants used in the experiment. The feeds were offered individually but always in binary choice with barley straw during the $4 \mathrm{~h}$ of test feeding for $7 \mathrm{~d}$ (named the "subperiod"). The number of subperiods depended on the number of test plants included in the experiment (5 and 6 in Exp. 1 and Exp. 2, respectively). The test plants were allocated randomly to the animals during the subperiods. Between the subperiods, the animals were fed barley straw only for $2 \mathrm{~d}$. The other treatment group (naïve) received only barley straw during the $4 \mathrm{~h}$ of test feeding. In Exp. 2, 1 animal of the naïve group had to be excluded due to illness. After the learning period, all animals from both treatment groups received 


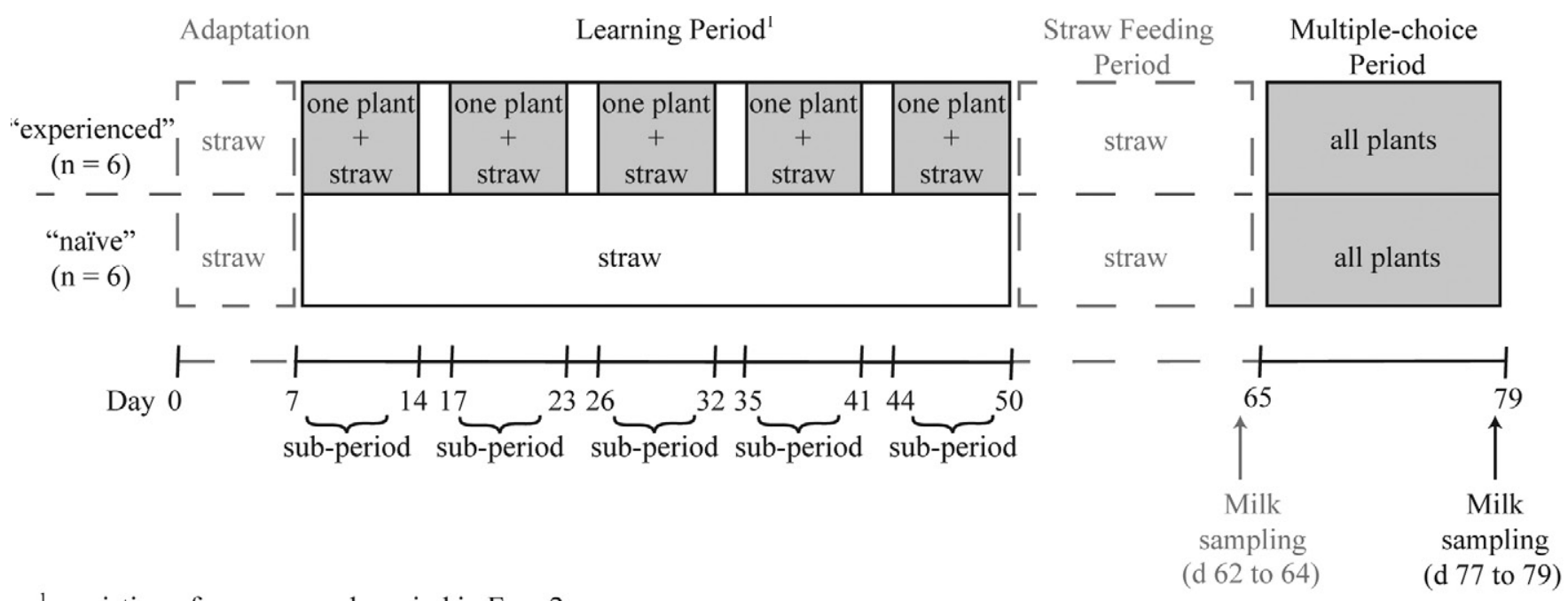

${ }^{1}$ consisting of one more sub-period in Exp. 2

Figure 1. Schedule of the feeding management performed in Exp. 1 and Exp. 2 with respect to the type of feeding accomplished during the daily $4 \mathrm{~h}$ of test feeding. Shaded areas reflect subperiods and periods of offering one or more test plants.

only the basal diet for $14 \mathrm{~d}$ ("straw feeding period") to minimize the carryover effects of the previous subperiod.

During the following 14-d multiple-choice period, all test plants (but no barley straw) were offered simultaneously in separate troughs for $4 \mathrm{~h}$ to both treatment groups. When the troughs were filled, the animals were either standing in the opposite corner of their pens due to shyness (Exp. 1) or were outside in the milking parlor (Exp. 2). This setup ensured that the animals could express their choice rather than start to feed on the feed provided first. The troughs were first refilled after 30 min and then periodically if needed to ensure that the feeds were always provided ad libitum. The allocation of the test plants to the troughs was changed every day to avoid habituation in feed position (Kaitho et al., 1996).

\section{Feeding-Related Measurements}

Individual feed intake was recorded separately for the $4 \mathrm{~h}$ of test feeding and for $24 \mathrm{~h}$. Refusals were recorded. As the animals did not noticeably select within feed type, refusals were not further analyzed for nutrient composition. The BW of the animals was determined in the morning before feeding (without previous fasting or water restriction) on $\mathrm{d} 1$ of each subperiod and period. The DMI was calculated from the as-fed intake data by using the DM content analyzed in the samples collected within the respective period. All intake data were analyzed and presented in relation to metabolic BW $\left(\mathrm{BW}^{0.75}\right)$. Feeding behavior was recorded using 4 camcorders (CANON Legria FS200; Tokyo, Japan) mounted on the ceiling of the barns in positions allowing a full view of all individual barns at the same time and on all troughs, which were labeled with numbers. In Exp. 2, 2 animals (1 per group) had to be housed in another part of the building. Thus, feeding behavior was assessed for 5 animals per treatment group. Behavioral variables included the time spent eating the individual test plants and the frequency of eating each test plant (i.e., the number of eating events). An eating event was defined as the period from when the animal put its head into the trough and showed jaw movements to when the animal moved its head away from the trough. Only the first $30 \mathrm{~min}$ of test feeding were considered for this analysis as most eating events occurred during this time. Afterward, the animals only occasionally resumed eating. The videos were analyzed with the behavior software INTERACT 9 (Mangold International GmbH, Arnstorf, Germany).

Feed samples were collected regularly ( 8 times in Exp. 1 and 4 times in Exp. 2), ground to pass through a $0.75-\mathrm{mm}$ sieve, and analyzed (AOAC, 1997) for DM and ash (AOAC International [AOAC] number 930.15). An air-circulation oven was used in Exp. 1, and a TGA701 (Leco Corporation, St. Joseph, MI) was used in Exp. 2. Feeds were also analyzed for NDF (with added $\alpha$-amylase), $\mathrm{ADF}$, and $\mathrm{ADL}$ (with $\mathrm{H}_{2} \mathrm{SO}_{4}$; Van Soest et al., 1991; AOAC number 973.18). In Exp. 2, a Fibertec System M (1020 Hot Extraction; Tecator, Flawil, Switzerland) was used and no $\mathrm{Na}_{2} \mathrm{SO}_{3}$ was added in the NDF analysis (Van Soest et al., 1991). All detergent fiber data are given excluding ash. In Exp. 1, N was analyzed according to the Kjedahl method (AOAC number 991.20) using a digestion block heater (Tector 2020; Foss, Hillerød, Denmark) and a distillation unit (Vapodest 30; Gerhardt GmbH, Königswinter, Germany). In Exp. 2, $\mathrm{N}$ was determined following AOAC method 977.02 using a C/N-Analyzer (Leco-Analyzer Typ FP2000; Leco Corporation, St. Joseph, MI). The CP content was computed as $6.25 \times \mathrm{N}$. Ether extract $(\mathrm{EE})$ was analyzed with Soxhlet extractors (Exp. 1: Soxtherms306 
A; Gerhardt GmbH, Königswinter, Germany; AOAC number 920.39; Exp. 2: Extractionssystem B-811; Büchi, Flawil, Switzerland; AOAC number 963.15). Total phenols (TP) and total tannins (TT) were analyzed with the Folin-Ciocalteau method (Makkar, 2003), but gallic acid was used. For condensed tannin (CT) analysis, the butanol-HCl-Fe method was applied, and the values are given as leucocyanidin equivalents. In Exp. 1, the content of digestible $\mathrm{OM}$ in $\mathrm{DM}$ was derived from in vitro incubation following Tilley and Terry's (1963) protocol. Sodium and $\mathrm{K}$ content was determined with the standard AOAC (2000) protocol. Non-NDF carbohydrates were calculated as $\mathrm{OM}$ minus NDF, CP, EE, and TP.

\section{Milk-Related Measurements}

The sheep were hand milked before feeding in the morning (starting at 0800 and $0900 \mathrm{~h}$ in Exp. 1 and 2, respectively) and in the late afternoon (starting at $1700 \mathrm{~h}$ ) either in their pens (Exp. 1) or in a milking parlor (Exp. $2)$. Milk yield $\left(\mathrm{g} \cdot \mathrm{head}^{-1} \cdot \mathrm{d}^{-1}\right)$ was recorded and the samples were immediately frozen at $-20^{\circ} \mathrm{C}$ on the last $3 \mathrm{~d}$ of the 14-d straw feeding period and on the last $3 \mathrm{~d}$ of the 14-d multiple-choice period. The defrosted samples were pooled to 1 sample per sheep and period considering the milk amounts obtained at the corresponding milking events. Fat, protein, and lactose content were determined with infrared-operated analyzers (Exp. 1: Milkoscan 133; Foss Electric, Hillerød, Denmark; Exp. 2: Combifoss FT; Foss Electric, Hillerød, Denmark in Bronopol conserved samples). In Exp. 1, total solids were determined with the same equipment whereas in Exp. 2 this was done with the standard AOAC (1997) protocol (number 930.15) using a TGA-701 (Leco Corporation, St. Joseph, MI). Solids nonfat were calculated as the difference of total solids and fat content. Because the infrared analyzer used in Exp. 2 was calibrated only for cow's milk, the values analyzed were adjusted to sheep milk values by using the regressions of the Arbeitsgemeinschaft Deutscher Rinderzüchter (ADR, 2002).

\section{Statistical Analysis}

Data were statistically analyzed with SAS 9.3 (SAS Inst. Inc., Cary, NC) using the MIXED procedure. Experimental unit was animal. All total forage intake data, total feeding time, and total number of eating events during the first 30 min of the $4 \mathrm{~h}$ of test feeding were statistically analyzed for group effects using model [1]:

$$
Y_{i j k}=\mu+G_{i}+D_{j}+(G \times D)_{i j}+\varepsilon_{i j k}
$$

in which the response variable was $Y$ and the fixed effects were $G$ (experienced vs. naïve groups), $D$ (day; repeated factor with the subject animal nested within group), and the interaction $G \times D$.

For analyzing the effect of the test plants on intake within $4 \mathrm{~h}$, feeding time, and number of eating events (first 30 min of the $4 \mathrm{~h}$ of test feeding), model [2] was used:

$$
\begin{aligned}
Y_{i j k l}=\mu & +F_{i}+G_{j}+D_{k}+(F \times G)_{i j} \\
& +(F \times D)_{i k}+(G \times D)_{j k} \\
& +(F \times G \times D)_{i j k}+\varepsilon_{i j k l},
\end{aligned}
$$

in which the fixed effects were $F$ (test feed), $G$ (group), $D$ (day; repeated factor as in model [1]), and the interactions among these effects. In Exp. 2, data on feeding time on the individual test plants were not normally distributed. Therefore, a logarithmic transformation of the data was applied before statistical analysis was conducted.

Nutrient intake (with and without concentrate) was analyzed from the DM intake and compositional data by using the means of the daily nutrient intakes during the multiple-choice period. Because of a nonnormal distribution, the nutrient intake data were logarithmically transformed before the statistical analysis was conducted with a simplified version of model [1] (model [1a]). Model [1a] did not include day as an effect but included animal nested within group as a random effect. Model [1a] was also used for analyzing nutrient intake on $\mathrm{d} 1$ and milk data. For the latter, the model included data measured in samples previously collected on the last days of the 14-d straw feeding period as covariates.

Data obtained separately for each treatment group on individual days were compared as follows. The total forage intake data were analyzed with model [1b], a simplification of model [1] that included only $D$ and not $G$. Data on intake, feeding time, and eating events concerning individual test plants were analyzed with another slightly modified model [1] to show changes over time separately by treatment group. This model (model [1c]) included $F$ instead of $G$ as a fixed effect. The results from models [1b] and [1c] were not shown in tables or figures.

The tables report the least square means. Multiple comparisons among the means of the test plants and days were made with Tukey's test. A level of $P<0.05$ was considered significant. Pearson correlation coefficients between intake, feeding time, eating events, and the nutrient composition of individual test plants were calculated with the CORR procedure of SAS. 
Table 2. Effect of experience on forage DM intake $(24 \mathrm{~h})$, straw intake $(20 \mathrm{~h})$, and test plant intake $(4 \mathrm{~h})$ in the multiple-choice period ${ }^{1}$

\begin{tabular}{|c|c|c|c|c|c|c|c|c|c|c|c|c|}
\hline Treatment & \multicolumn{4}{|c|}{ wk 1 to $2, \mathrm{~g} / \mathrm{kg} \mathrm{BW}^{0.75}$} & \multicolumn{4}{|c|}{ d 1 to $3, \mathrm{~g} / \mathrm{kg} \mathrm{BW}^{0.75}$} & \multicolumn{4}{|c|}{ d 12 to $14, \mathrm{~g} / \mathrm{kg} \mathrm{BW}^{0.75}$} \\
\hline \multicolumn{13}{|l|}{ Experiment 1} \\
\hline Straw, $20 \mathrm{~h}$ & 28.0 & 27.0 & 2.43 & 0.76 & 28.7 & 26.2 & 2.65 & 0.51 & 28.5 & 28.6 & 2.23 & 0.98 \\
\hline Plants, 4 h & 16.1 & 16.8 & 1.31 & 0.70 & 15.2 & 15.8 & 1.17 & 0.70 & 17.1 & 19.2 & 1.77 & 0.42 \\
\hline Artemisia herba-alba & $0.1^{\mathrm{c}}$ & $0.3^{\mathrm{c}}$ & 2 & & $0.1^{\mathrm{c}}$ & $0.2^{\mathrm{c}}$ & 3 & & $0.3^{\mathrm{d}}$ & $0.8^{\mathrm{cd}}$ & 4 & \\
\hline Haloxylon articulatum & $0.2^{\mathrm{c}}$ & $0.1^{\mathrm{c}}$ & & & $0.7^{\mathrm{c}}$ & $0.1^{\mathrm{c}}$ & & & $0.0^{\mathrm{d}}$ & $0.0^{\mathrm{d}}$ & & \\
\hline Noaea mucronata & $0.0^{\mathrm{c}}$ & $0.0^{\mathrm{c}}$ & & & $0.0^{\mathrm{c}}$ & $0.0^{\mathrm{c}}$ & & & $0.0^{\mathrm{d}}$ & $0.0^{\mathrm{d}}$ & & \\
\hline Salsola vermiculata & $3.6^{\mathrm{b}}$ & $3.5^{\mathrm{b}}$ & & & $3.7^{\mathrm{b}}$ & $3.0^{\mathrm{b}}$ & & & $3.8^{\mathrm{bc}}$ & $3.9^{\mathrm{b}}$ & & \\
\hline \multicolumn{13}{|l|}{ Experiment 2} \\
\hline Forage DM, 24 h & 74.9 & 65.7 & 5.04 & 0.23 & 66.3 & 58.0 & 3.73 & 0.15 & 85.7 & 71.9 & 6.27 & 0.16 \\
\hline Castanea sativa & $0.3^{\mathrm{e}}$ & $0.6^{\mathrm{de}}$ & & & $0.7^{\mathrm{b}}$ & $1.2^{\mathrm{b}}$ & & & $0.2^{\mathrm{cd}}$ & $0.5^{\mathrm{d}}$ & & \\
\hline H. articulatum & $0.1^{\mathrm{e}}$ & $0.2^{\mathrm{de}}$ & & & $0.1^{\mathrm{b}}$ & $0.3^{\mathrm{b}}$ & & & $0.2^{\mathrm{cd}}$ & $0.2^{\mathrm{d}}$ & & \\
\hline Juglans regia & $1.3^{\mathrm{ce}}$ & $0.8^{\mathrm{de}}$ & & & $5.0^{\mathrm{b}}$ & $3.2^{\mathrm{b}}$ & & & $0.1^{\mathrm{cd}}$ & $0.1^{\mathrm{d}}$ & & \\
\hline S. vermiculata & $0.0^{\mathrm{e}}$ & $0.1^{\mathrm{de}}$ & & & $0.1^{\mathrm{b}}$ & $0.3^{\mathrm{b}}$ & & & $0.0^{\mathrm{cd}}$ & $0.0^{\mathrm{d}}$ & & \\
\hline
\end{tabular}

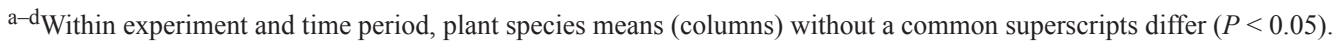

${ }^{1}$ Exp. 1: $n=6$ experienced and $n=6$ naïve animals; Exp. 2: $n=6$ experienced and $n=5$ naïve animals.

${ }^{2,3,4} P$-values and SEM for treatment, plant, and interaction of treatment and of plant species (Exp. 1): $P=0.70$ and $\mathrm{SEM}=0.26, P<0.001$ and SEM $=0.24$, and $P=0.20$ and $\mathrm{SEM}=0.33$ for wk 1 and $2 ; P=0.70$ and $\mathrm{SEM}=0.23, P<0.001$ and $\mathrm{SEM}=0.32$, and $P=0.061$ and $\mathrm{SEM}=0.45$ for $\mathrm{d} 1$ to $3 ; P=0.42$ and $\mathrm{SEM}=0.35, P<0.001$ and SEM $=0.46$, and $P=0.71$ and $\mathrm{SEM}=0.64$ for $\mathrm{d} 12$ to 14 , respectively.

${ }^{5,6,7} P$-values and SEM for treatment, plant, and interaction of treatment and of plant species (Exp. 2): $P=0.89$ and SEM $=0.66, P<0.001$ and SEM $=0.60$, and $P=0.039$ and $\mathrm{SEM}=0.81$ for wk 1 and $2 ; P=0.77$ and $\mathrm{SEM}=0.47, P<0.001$ and $\mathrm{SEM}=0.99$, and $P=0.88$ and $\mathrm{SEM}=1.40$ for $\mathrm{d} 1$ to $3 ; P=0.55$ and $\mathrm{SEM}=0.92, P<0.001$ and $\mathrm{SEM}=0.97$, and $P=0.045$ and $\mathrm{SEM}=1.37$ for $\mathrm{d} 12$ to 14 , respectively.

\section{RESULTS}

\section{Experimental Feeds}

The test plants clearly differed in fiber content (Table 1). Noaea mucronata and S. vermiculata were the most fibrous with approximately 65\% NDF (DM basis). The other test plants contained between 40 and $50 \%$ NDF. Most test plants contained substantial levels of ADL; A. leucoclada and $H$. articulatum were the plants with the lowest ADL content. Except for $N$. mucronata, the plants contained at least $12 \% \mathrm{CP}$ (DM basis), with the greatest amount measured in A. leucoclada. The test plants therefore contained more $\mathrm{CP}$ than the straw used in both experiments (4 to $6 \% \mathrm{CP}$, respectively; DM basis). Greater amounts of phenolic compounds were measured in the plants from the temperate climate $(3.0$ to $5.0 \% \mathrm{TP}$, respectively; DM basis) than in the Mediterranean plants ( 0.5 to $2.5 \%$, respectively; DM basis), and the plants from the temperate climate contained more OM. Saltbush (A. leucoclada) had the greatest content (in percent of DM) of $\mathrm{Na}$ (3.0) and $\mathrm{K}$ (2.3) compared to the other Mediterranean plants (Na: from 0.7 to $1.8 ; \mathrm{K}$ : from 1.3 to 2.1 ; data not shown).

\section{Effect of Experience on DM Intake and Plant Species Intake}

Experience had no significant $(P \geq 0.05)$ effect on intake in either experiment (Table 2). One exception was the greater total daily forage and total straw intake on $\mathrm{d} 1$ by the experienced animals in Exp. 2 compared to the naïve group $(P=0.015$ and $P=0.004$, respectively; data not shown). Forage DM intake was affected by day $(P<0.01$ for naïve group in Exp. 1; $P$ $<0.001$ for both groups in Exp. 2). Additionally, there were day-to-day variations in straw intake $(P<0.001$ for both groups in Exp. 2) and total test plant intake $(P$ $<0.001$ for naïve group in Exp. $1 ; P<0.001$ for both groups in Exp. 2; data not shown). In Exp. 2 on $\mathrm{d} 2$ and 3, forage DM intake was lower $(P<0.05)$ in both groups than on $\mathrm{d} 14$ and total test plant intake as well as intake of $B$. pendula was lower $(P<0.05)$ in both groups on $\mathrm{d} 2$ than on $\mathrm{d} 14$ (data not shown). 
Table 3. Effect of experience on feeding time ( $\mathrm{min}$ ) of the individual test plants and of all plants (total time) during the first 30 min of the test feeding in the multiple-choice period ${ }^{1}$

\begin{tabular}{|c|c|c|c|c|c|c|c|c|c|c|c|c|}
\hline Treatment & \multicolumn{3}{|c|}{ wk 1 to 2} & $P$ & \multicolumn{3}{|c|}{ d 1 to 3} & $P$ & \multicolumn{3}{|c|}{ d 12 to 14} & $P$ \\
\hline \multicolumn{13}{|l|}{ Experiment 1} \\
\hline Artemisia herba-alba & $0.1^{\mathrm{c}}$ & $0.7^{\mathrm{c}}$ & 2 & & $0.4^{\mathrm{c}}$ & $1.6^{\mathrm{bc}}$ & 3 & & $0.1^{\mathrm{d}}$ & $0.5^{\mathrm{d}}$ & 4 & \\
\hline Atriplex leucoclada & $14.9^{\mathrm{a}}$ & $17.3^{\mathrm{a}}$ & & & $15.5^{\mathrm{a}}$ & $15.0^{\mathrm{a}}$ & & & $13.4^{\mathrm{ab}}$ & $16.1^{\mathrm{a}}$ & & \\
\hline Haloxylon articulatum & $0.3^{\mathrm{c}}$ & $0.3^{\mathrm{c}}$ & & & $1.0^{\mathrm{c}}$ & $0.6^{\mathrm{c}}$ & & & $0.1^{\mathrm{d}}$ & $0.3^{\mathrm{d}}$ & & \\
\hline Salsola vermiculata & $7.2^{\mathrm{b}}$ & $5.8^{\mathrm{b}}$ & & & $5.9^{\mathrm{b}}$ & $3.9^{\mathrm{bc}}$ & & & $9.6^{\mathrm{bc}}$ & $7.7^{\mathrm{c}}$ & & \\
\hline \multicolumn{13}{|l|}{ Experiment 2} \\
\hline Total time & 18.3 & 20.3 & 1.59 & 0.44 & 11.5 & 15.2 & 1.51 & 0.13 & 21.3 & 24.3 & 2.19 & 0.36 \\
\hline A. leucoclada & $6.2^{\mathrm{b}}$ & $7.9^{\mathrm{ab}}$ & 5 & & $2.6^{\mathrm{abc}}$ & $2.7^{\mathrm{ab}}$ & 6 & & $7.5^{\mathrm{a}}$ & $10.9^{\mathrm{a}}$ & 7 & \\
\hline Betula pendula & $11.0^{\mathrm{a}}$ & $10.7^{\mathrm{ab}}$ & & & $6.2^{\mathrm{ab}}$ & $7.2^{\mathrm{a}}$ & & & $13.3^{\mathrm{a}}$ & $13.0^{\mathrm{a}}$ & & \\
\hline
\end{tabular}

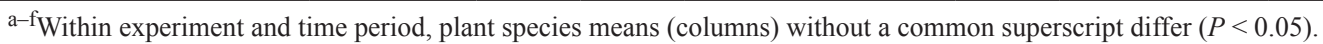

${ }^{1}$ Exp. 1: $n=6$ experienced and $n=6$ naïve animals; Exp. 2: $n=6$ experienced and $n=5$ naïve animals.

${ }^{2,3,4} P$-values and SEM for treatment, plant, and interaction of treatment and of plant species (Exp. 1): $P=0.56$ and SEM $=0.345, P<0.001$ and SEM $=0.370$, and $P=0.003$ and $\mathrm{SEM}=0.523$ for wk 1 and $2 ; P=0.63$ and $\mathrm{SEM}=0.459, P<0.001$ and $\mathrm{SEM}=0.669$, and $P=0.52$ and $\mathrm{SEM}=0.946$ for $\mathrm{d} 1$ to $3 ; P=0.59$ and $\mathrm{SEM}=0.365, P<0.001$ and $\mathrm{SEM}=0.692$, and $P=0.28$ and $\mathrm{SEM}=0.978$ for $\mathrm{d} 12$ to 14 .

${ }^{5,6,7} P$-values and SEM for treatment, plant, and interaction of treatment and of plant species (Exp. 2): $P=0.086$ and SEM $=0.265, P<0.001$ and SEM $=$ 0.276 , and $P=0.68$ and $\mathrm{SEM}=0.383$ for wk 1 and $2 ; P=0.042$ and $\mathrm{SEM}=0.234, P<0.001$ and $\mathrm{SEM}=0.440$, and $P=0.87$ and $\mathrm{SEM}=0.615$ for $\mathrm{d} 1$ to $3 ; P=$ 0.96 and $\mathrm{SEM}=0.078, P<0.001$ and $\mathrm{SEM}=0.417$, and $P=0.75$ and $\mathrm{SEM}=0.581$ for $\mathrm{d} 12$ to 14 , respectively.

Atriplex leucoclada was the most $(P<0.05)$ consumed test plant in Exp. 1 followed by $S$. vermiculata in both groups (Table 2). The other 3 test plants were almost completely rejected. In Exp. 2, the most $(P<$ $0.05)$ consumed test plant in both treatments across the entire multiple-choice period (wk 1 and 2) was B. pendula followed by A. leucoclada. The other 4 test plants were eaten in comparably low amounts. In both treatment groups, $B$. pendula was the preferred $(P<0.05)$ test plant from the beginning (d 1 to 3 ).

\section{Effect of Experience on Feeding Behavior}

Across the entire multiple-choice period, experience had no significant influence $(P \geq 0.05)$ on total feeding time on the test plants in both experiments (Table 3 ). In detail, in Exp. 1 across groups and experimental weeks the sheep ate the longest $(P<0.05)$ from $A$. leucoclada (15 and 17 min for experienced and naïve groups, respectively) followed by $S$. vermiculata ( 7 and 6 min for experienced and naïve groups, respectively). The other test plants were almost completely ignored $(<1 \mathrm{~min}$ for both treatment groups). Feeding time did not significantly $(P \geq 0.05)$ differ between days in Exp. 1 (data not shown). In Exp. 2, the experienced sheep fed the longest $(P<0.05)$ on $B$. pendula followed by $A$. leucoclada compared to the other test plants (Table 3 ). The naïve animals ate $A$. leucoclada and B. pendula for a similarly $(P \geq 0.05)$ long period (Table 3$)$. The other test plants were eaten for $<1 \mathrm{~min}$ in both groups across both experimental weeks. In Exp. 2, day had an effect $(P<0.001)$ on total feeding time and feeding time on individual test plants ( $P \leq 0.001$; data not shown). On d 1 to 3 of Exp. 2 , the animals in both treatments exhibited similar $(P \geq$ 0.05 ) feeding times for $A$. leucoclada, B. pendula, and $J$. regia. On d 12 to 14, sheep in both treatment groups fed the longest $(P<0.05)$ on $A$. leucoclada and B. pendula whereas the time spent feeding on the other test plants was $<1$ min (Table 3). In Exp. 2 , in both groups, the total feeding time was shorter $(P<0.05)$ on $\mathrm{d} 2$ and 3 than on d 14 and the feeding time on $J$. regia was longer $(P<$ 0.05 ) on $\mathrm{d} 1$ than on $\mathrm{d} 14$ (data not shown).

Experience also had no significant effect $(P=0.16$ and $P=0.19$ for Exp. 1 and Exp. 2, respectively) on the number of eating events across the entire multiplechoice period (Table 4). On d 1 to 3 (but not on d 12 to 14) of Exp. 2, the total number of eating events was greater $(P=0.021)$ in the naïve group. In Exp. 1 , the number of eating events was greatest $(P<0.05)$ for the most preferred test plant (A. leucoclada) followed by $S$. vermiculata for both treatment groups. In Exp. 2, most $(P<0.05)$ eating events occurred with $B$. pendula and A. leucoclada across the entire experiment and on $\mathrm{d} 12$ to 14 . In both experiments, total eating events varied 
Table 4. Effect of experience on number of eating events on the individual test plants and on all plants (total events) during the first 30 min of the test feeding in the multiple-choice period ${ }^{1}$

\begin{tabular}{|c|c|c|c|c|c|c|c|c|c|c|c|c|}
\hline \multirow[b]{2}{*}{ Treatment } & \multicolumn{3}{|c|}{ wk 1 to 2} & \multirow[b]{2}{*}{$P$} & \multicolumn{3}{|c|}{ d 1 to 3} & \multirow[b]{2}{*}{$P$} & \multicolumn{3}{|c|}{ d 12 to 14} & \multirow[b]{2}{*}{$P$} \\
\hline & Experienced & Naïve & SEM & & Experienced & Naïve & SEM & & Experienced & Naïve & SEM & \\
\hline \multicolumn{13}{|l|}{ Experiment 1} \\
\hline Artemisia herba-alba & $0.7^{\mathrm{d}}$ & $1.6^{\mathrm{d}}$ & 2 & & $1.3^{\mathrm{d}}$ & $3.6^{\mathrm{bcd}}$ & 3 & & $0.4^{\mathrm{d}}$ & $1.3^{\mathrm{cd}}$ & 4 & \\
\hline Atriplex leucoclada & $6.3^{\mathrm{b}}$ & $8.8^{\mathrm{a}}$ & & & $6.4^{\mathrm{ab}}$ & $7.7^{\mathrm{a}}$ & & & $5.4^{\mathrm{ab}}$ & $8.6^{\mathrm{a}}$ & & \\
\hline Haloxylon articulatum & $1.3^{\mathrm{d}}$ & $1.6^{\mathrm{d}}$ & & & $2.9^{\mathrm{cd}}$ & $2.7^{\mathrm{bcd}}$ & & & $0.5^{\mathrm{d}}$ & $1.1^{\mathrm{cd}}$ & & \\
\hline Salsola vermiculata & $4.4^{\mathrm{c}}$ & $5.3^{\mathrm{bc}}$ & & & $5.7^{\mathrm{abc}}$ & $4.6^{\mathrm{abcd}}$ & & & $4.1^{b c}$ & $6.7^{\mathrm{ab}}$ & & \\
\hline \multicolumn{13}{|l|}{ Experiment 2} \\
\hline Total events & 18.5 & 21.7 & 1.57 & 0.19 & 16.8 & 25.3 & 2.06 & 0.021 & 23.2 & 22.9 & 2.29 & 0.94 \\
\hline A. leucoclada & $7.6^{\mathrm{a}}$ & $8.8^{\mathrm{a}}$ & 5 & & $4.5^{\text {bcd }}$ & $4.9^{\mathrm{bc}}$ & 6 & & $10.6^{\mathrm{a}}$ & $11.4^{\mathrm{a}}$ & 7 & \\
\hline Betula pendula & $8.5^{\mathrm{a}}$ & $8.8^{\mathrm{a}}$ & & & $5.8^{\mathrm{ab}}$ & $8.4^{\mathrm{a}}$ & & & $11.4^{\mathrm{a}}$ & $10.3^{\mathrm{a}}$ & & \\
\hline Castanea sativa & $0.7^{\mathrm{b}}$ & $1.5^{\mathrm{b}}$ & & & $1.7^{\mathrm{cde}}$ & $2.9^{\text {bcde }}$ & & & $0.5^{\mathrm{b}}$ & $1.1^{\mathrm{b}}$ & & \\
\hline
\end{tabular}

${ }^{\mathrm{a}-\mathrm{e}}$ Within experiment and time period, plant species means (columns) without a common superscripts differ $(P<0.05)$.

${ }^{1}$ Exp. 1: $n=6$ experienced and $n=6$ naïve animals; Exp. 2: $n=6$ experienced and $n=5$ naïve animals.

${ }^{2,3,4} P$-values and SEM for treatment, plant, and interaction of treatment and of plant species (Exp. 1): $P=0.16$ and SEM $=0.464, P<0.001$ and SEM $=0.367$, and $P=0.001$ and $\mathrm{SEM}=0.518$ for wk 1 and $2 ; P=0.52$ and $\mathrm{SEM}=0.58, P<0.001$ and $\mathrm{SEM}=0.593$, and $P=0.14$ and $\mathrm{SEM}=0.839$ for $\mathrm{d} 1$ to $3 ; P=0.12$ and $\mathrm{SEM}=0.609, P<0.001$ and $\mathrm{SEM}=0.531$, and $P=0.011$ and $\mathrm{SEM}=0.751$ for $\mathrm{d} 12$ to 14 .

5,6,7 $P$-values and SEM for treatment, plant, and interaction of treatment and of plant species (Exp. 2): $P=0.18$ and SEM $=0.237, P<0.001$ and SEM $=0.269$, and $P=0.55$ and $\mathrm{SEM}=0.374$ for wk 1 and $2 ; P=0.021$ and $\mathrm{SEM}=0.31, P<0.001$ and $\mathrm{SEM}=0.479$, and $P=0.36$ and $\mathrm{SEM}=0.670$ for $\mathrm{d} 1$ to $3 ; P=0.94$ and $\mathrm{SEM}=0.384, P<0.001$ and $\mathrm{SEM}=0.510$, and $P=0.70$ and $\mathrm{SEM}=0.711$ for $\mathrm{d} 12$ to 14 .

$(P<0.05)$ between days (data not shown). In Exp. 1, total eating events were more numerous $(P<0.001)$ on $\mathrm{d} 1$ and $\mathrm{d} 4$ than on $\mathrm{d} 14$ in both treatment groups (data not shown). In Exp. 2, the interaction between day and test plants was significant $(P<0.001)$ in both groups with more frequent $(P<0.05)$ eating events in $J$. regia on $\mathrm{d} 1$ and less frequent $(P<0.05)$ eating events in $A$. leucoclada on d 2 and 3 compared to d 14 in both treatment groups (data not shown).

In Exp. 1, the duration of the single eating events (data not shown) was similar between groups and longest $(P<0.05)$ for A. leucoclada $(2.9$ and $2.7 \mathrm{~min}$ per eating event for experienced and naïve sheep, respectively) followed by $S$. vermiculata (1.5 and 1.0 min for experienced and naïve sheep, respectively). The time spent feeding per eating event for the other 3 plants was less than 0.3 min in both groups. In Exp. 2, the eating events were longest $(P<0.05)$ for $B$. pendula $(1.4 \mathrm{~min}$ in both groups) followed by A. leucoclada (0.8 and 0.9 min for the experienced group and the naïve group, respectively). The eating events for the other plants were shorter $(P<0.05)$ with $<0.2$ min. In Exp. 2 , the duration of a single eating event varied between days $(P<0.05)$ in the naïve group. In $B$. pendula, the feeding events lasted for $0.5 \mathrm{~min}$ on $\mathrm{d} 1$ and $6,2.3 \mathrm{~min}$ on $\mathrm{d} \mathrm{5}$, and 2.0 min on $\mathrm{d} 7$ in the naïve group (data not shown).

\section{Effect of Experience on Total Daily Nutrient Intake and Performance}

Nutrient intakes were not significantly different $(P \geq$ 0.05 ) between the experienced and naïve sheep (Table 5). However, in Exp. 2 on $d 1$ the experienced animals consumed more $(P<0.05) \mathrm{NDF}$ and ADF and there was a trend $(P<0.1)$ for greater ADL intake when the nutrients obtained from the test plants, straw, and concentrate are included (data not shown). In Exp. 2, when only the nutrients ingested from the forages are considered, on $\mathrm{d} 1$ the OM, NDF, ADF, and ADL intakes were greater $(P<0.05)$ and there was a trend $(P<0.1)$ for greater EE, non-NDF carbohydrates, and TP intakes in the experienced group compared to the naïve group (data not shown). Experience with the test plants had no systematic effect on milk yield and milk composition.

\section{Correlations between Intake and Feeding Behavior and Nutrient Composition of Test Plants}

There were close positive relationships between test plant intake and feeding behavior $(P<0.001$; Table 6$)$. The NDF, ADF, ADL, and TP content of the test plants was negatively (all $P<0.001$ ) and the $\mathrm{CP}$, digestible $\mathrm{OM}$ (both $P<0.001)$, and non-NDF carbohydrates $(P<0.01)$ content of the test plants was positively related to test plant intake in Exp. 1 (Table 6). In Exp. 2, a positive relationship 
Table 5. Effect of experience on total daily nutrient intake and performance in the multiple-choice period ${ }^{1}$

\begin{tabular}{|c|c|c|c|c|c|c|c|c|}
\hline \multicolumn{9}{|c|}{ Nutrient intake, g DM, kg BW ${ }^{-0.75} \cdot \mathrm{d}^{-1}$} \\
\hline $\mathrm{CP}$ & $11.9(3.1)$ & $12.2(3.1)$ & $0.45(0.21)$ & $0.68(0.99)$ & $16.7(7.5)$ & $18.6(7.0)$ & $0.81(0.66)$ & $0.13(0.52)$ \\
\hline Ether extract & $1.1(0.3)$ & $1.1(0.3)$ & $0.04(0.02)$ & $0.73(0.92)$ & $3.5(1.9)$ & $3.7(1.7)$ & $0.16(0.16)$ & $0.35(0.41)$ \\
\hline NDF & $41.8(27.9)$ & $41.9(27.5)$ & $2.31(2.08)$ & $0.93(0.80)$ & $56.3(48.5)$ & $51.3(41.4)$ & $2.77(3.39)$ & $0.23(0.17)$ \\
\hline $\mathrm{ADL}$ & $2.9(2.4)$ & $3.0(2.4)$ & $0.18(0.19)$ & $0.96(0.99)$ & $10.5(9.3)$ & $9.8(8.3)$ & $0.61(0.69)$ & $0.40(0.31)$ \\
\hline Non-NDF carbohydrates & $-(6.6)$ & $-(6.7)$ & $-(0.44)$ & $-(0.97)$ & $23.4(10.4)$ & $25.9(9.4)$ & $1.17(0.82)$ & $0.18(0.40)$ \\
\hline Digestible OM & $51.3(20.1)$ & $52.2(19.9)$ & $2.06(1.37)$ & $0.83(0.86)$ & $-(-)$ & $-(-)$ & $-(-)$ & $-(-)$ \\
\hline Total phenols & $-(0.3)$ & $-(0.3)$ & $-(0.02)$ & $-(0.91)$ & $1.4(1.3)$ & $1.3(1.1)$ & $0.10(0.11)$ & $0.57(0.44)$ \\
\hline Milk yield, ${ }^{3} \mathrm{~g} \mathrm{head}^{-1} \cdot \mathrm{d}^{-1}$ & 194 & 185 & 23.1 & 0.81 & 555 & 610 & 52.8 & 0.53 \\
\hline Total solids & 18.1 & 17.8 & 0.411 & 0.66 & 15.4 & 15.4 & 0.308 & 0.97 \\
\hline Solids nonfat & 11.5 & 11.7 & 0.186 & 0.54 & 11.0 & 11.2 & 0.071 & 0.075 \\
\hline
\end{tabular}

${ }^{1}$ Exp. 1: $n=6$ experienced and $n=6$ naïve animals; Exp. 2: $n=6$ experienced and $n=5$ naïve animals.

${ }^{2}$ Least square means of nutrient intake including concentrate. Values in brackets are least square means of nutrient intake from forage only.

${ }^{3}$ Including the milk yield and composition measured at the last $3 \mathrm{~d}$ of the $14 \mathrm{~d}$ of straw feeding only as covariable in the model.

between the test plant intake and the nutrient composition of OM, ADL (both $P<0.001)$, EE $(P<0.01)$, and nonNDF carbohydrates $(P<0.05)$ was found (Table 6$)$.

\section{DISCUSSION}

In the present study, 2 experiments were performed to evaluate intake of dried woody plants in sheep under different environmental, genotypic, and test feed conditions and whether experience is advantageous in a multiple-choice situation. Straw was used as the control feed in both experiments; however, the straw used in Exp. 1 was of clearly higher nutritional quality than that used in Exp. 2. The latter was a conventional straw from barley genotypes bred for high grain yield. The straw in Exp. 1 originated from ICARDA, Syria, an institute that selects barley cultivars not only for their grain yield (as is done in Europe) but also for the high quality of the harvest residue because in dry areas straw is typically used as a feed. This strategy dates to the 1980s (Capper et al., 1986). The greater straw intake in Exp. 2 was unexpected (as was the greater intake of the woody forages). This finding seems to have been due to a breed difference. These differences between the experiments, however, do not interfere with the intention of the study, which focused on determining the effect of experience under different conditions and not on comparing the individual findings of the 2 experiments. Care has to be taken when applying the present results obtained with dried plant material to fresh plant material, as the
Table 6. Correlation coefficients between test plant intake and feeding behavior as well as test plant nutrient content in the multiple-choice period ( $n=60$ and $n=72$ in Exp. 1 and Exp. 2, respectively)

\begin{tabular}{lcc}
\hline \hline & \multicolumn{2}{c}{ Test plant intake, $4 \mathrm{~h}$} \\
\cline { 2 - 3 } Experiment & 1 & 2 \\
\hline Feeding behavior ${ }^{1}$ & $0.96^{* * *}$ & $0.86^{* * *}$ \\
Feeding time & $0.83^{* * *}$ & $0.74 * * *$ \\
Eating events & & \\
Nutrient contents & $-0.73^{* * *}$ & $0.45^{* * *}$ \\
OM & $0.65^{* * *}$ & 0.12 \\
$\mathrm{CP}$ & 0.08 & $0.32^{* *}$ \\
Ether extract & $-0.52^{* * *}$ & -0.09 \\
NDF & $-0.68^{* * *}$ & -0.19 \\
ADF & $-0.69^{* * *}$ & $0.63^{* * *}$ \\
ADL & $0.40^{* *}$ & $0.28^{*}$ \\
Non-NDF CHO & $0.67^{* * *}$ & - \\
Digestible OM & $-0.46^{* * *}$ & 0.11 \\
Total phenols &
\end{tabular}

${ }^{1}$ Correlation coefficients between feeding time and number of eating events were $0.82(P<0.001)$ and $0.95(P<0.001)$ for Exp. 1 and for Exp. 2, respectively.

${ }^{2}$ Non-NDF CHO $=$ non-NDF carbohydrates.

*** $P<0.001 ; * * P<0.01 ; * P<0.05$ 
chemical composition might have been changed by the drying process (Ahn et al., 1989). Other factors of influence, not accounted for, might be the type and number of different feeds (test feeds as well as basal diet) offered, the duration of test feeding, total nutrient supply, animal species, and animals' age.

\section{Importance of Experience in a Multiple-Choice Situation with Woody Forages}

Authors of several previous studies considered experience to influence feed intake and feeding behavior (Flores et al., 1989; Ortega-Reyes and Provenza, 1993; Ganskopp and Cruz, 1999; Catanese et al., 2010), especially when forages are of low quality (Distel et al., 1996) or are rich in plant secondary compounds (PSC) such as woody plants (Bryant et al., 1991). Experience with feeds containing PSC appears to enhance their intake (Villalba et al., 2004; Ben Salem et al., 2005). Additionally, experience helps animals overcome feed neophobia faster (Catanese et al., 2012) and thus avoid reluctant ingestion of novel feeds (Forbes, 2007) and realize larger total intakes (Nolte and Provenza, 1992). However, in the 2 current experiments experience had no effect on intake, preference, and feeding behavior. Consequently, no influence of experience on milk yield and composition were found. Experience was expected to affect eating efficiency through better foraging skills (higher intake, intake rates, and bite rates of experienced animals; Flores et al., 1989; Ortega-Reyes and Provenza, 1993) and preference pattern. However, experience did not lead to a change in preference ranking in the present study; therefore, either experience with the tested plants was not that important for the animals or the animals were able to learn and adapt to new feeds quickly. The latter assumption is supported by Ganskopp and Cruz's (1999) findings that naïve steers expressed a similar preference ranking for 8 grass species compared to experienced steers after $5 \mathrm{~min}$ of access but that naïve animals were less efficient (fewer bites per grazing session). However, it has to be taken into account that in the present study dried woody plants were used. A small but significant initial (d 1 to 3 ) effect of experience occurred in Exp. 2 in which naïve sheep showed a greater number of total eating events than experienced sheep, which might be an example of less efficient feeding behavior at initial exposure to novel plants. Additionally, the experienced sheep's nutrient intake (OM and fiber) and intake of total forage was larger on $\mathrm{d} 1$. The higher number of eating events reported for both groups on $\mathrm{d} 1$ and 4 compared to d 14 in Exp. 1 suggests that the animals might have been generally initially uncertain about the novel feeds. Initial differences in intake were also found by Kaitho et al. (1996). The smaller initial effect observed in Exp.
1 might be explained by the sheep's general experience with low-quality forages, which were not common in the feeding of the Swiss experimental sheep. Another explanation could be that the plants tested in Exp. 2 required more experience to be properly ingested due to their greater PSC content than the plants tested in Exp. 1.

Several researchers found that the effect of experience persisted for several months after the last exposure to the test feeds (Distel et al., 1996; Villalba et al., 2004; Catanese et al., 2012). Therefore, in the present study the effect of experience should have persisted longer than from the end of the learning period to the beginning of the multiple-choice period ( $2 \mathrm{wk}$ ). Even though most of these studies were done with lambs that had been weaned (Villalba et al., 2004; Catanese et al., 2012) and thus no longer in the sensitive period (4 to $8 \mathrm{wk}$ of age; Oh et al., 1972), learning through feed imprinting (Provenza and Balph, 1988) could not have been expected in this study. However, young lambs probably depend more on experience than adult sheep.

Experience could also be gained through social learning, especially by imitating the behavior of conspecifics (Provenza and Balph, 1988). However, the design of the present study did not allow social learning because the animals were housed individually. Therefore, the animals assumingly gained experience through trial and error (Provenza et al., 1992); that is, novel feeds were cautiously sampled to minimize the risk of toxicity (du Toit et al., 1991). This sampling behavior was assumed to have occurred in the present study in the naïve group in Exp. 2, with greater counts of eating events in the naïve group compared to the experienced group on $d$ 1 to 3 . A further indication of sampling behavior might be the fluctuations in the duration of the single eating events involving $B$. pendula until $\mathrm{d} 7$ in the naïve group.

When offered high- and low-quality feed simultaneously, experienced lambs reduced their intake of the lowquality feed more than inexperienced lambs (Catanese et al., 2010). Therefore, no access to the concentrate was provided during the $4 \mathrm{~h}$ daily test period in the present study. However, the sheep had the opportunity to cover their requirements for maintenance and milk production with concentrate during the rest of the day. As straw was also available for the rest of the day, the animals had also the possibility to balance their diet (high concentrate intake) with a fibrous feed. Thus, hunger did not affect the feed choice (Provenza et al., 2007).

\section{Preference for Individual Test Plants}

The most preferred plants in the 2 experiments comprised around $80 \%$ of the total test plant intake and 30 (Exp. 1) to $37 \%$ (Exp. 2) of the total forage intake. Atriplex leucoclada was the most consumed test 
plant in Exp. 1 and the second most consumed in Exp. 2. This plant had the greatest feeding value among the test plants offered (low fiber, lignin, and TP and high $\mathrm{CP}$ content). Researchers have shown that $A$. leucoclada is consumed by ruminants in rangelands (Murad, 2000). Abbeddou et al. (2011) observed that only a few sheep refused parts of a diet containing more than $70 \%$ Atriplex (here Atriplex halimus with an even 3 times greater salt content), which demonstrates the high palatability of several members of the Atriplex family. In cases of $\mathrm{NaCl}$ deficiency, A. leucoclada might be eaten because of its high $\mathrm{NaCl}$ content. However, this was clearly not the case in the present study in which the animals were supplemented with enough $\mathrm{NaCl}$. Salsola vermiculata was the second most consumed test plant in Exp. 1. This plant has been described as highly palatable (Tadros, 2000) and is an important fodder shrub in Syria (Murad, 2000). Betula pendula is known to be eaten by ruminants in rangelands (Shipley et al., 1998). The remaining plants were eaten in low amounts when offered in a multiple-choice situation. Apart from considerable lignin or phenol content or both, reasons for low intake could include an unfavorable physical structure. Noaea mucronata was bulky and spiny. Haloxylon articulatum was also bulky and had the greatest TP content among the test plants in Exp. 1 together with $A$. herba-alba. In addition, $A$. herba-alba contains high amounts of essential oils (Yashphe et al., 1987), which might be associated with low palatability. Castanea sativa and J. regia are rich in TP and TT, and the phenolic compounds in J. regia show antibacterial activity (Pereira et al., 2007), which might have adverse effects on ruminal digestion. The comparably high intake of $J$. regia occurring on d 1 could therefore indirectly be the reason for the severely decreased intake of total forage and total test plants on $\mathrm{d}$ 2. The relationship between the feeding value of the test plants and the individual plant intake was confirmed by the significant correlations found in both experiments.

Small amounts of the unpalatable plants were consumed, which might be an indication for ongoing sampling behavior. This included not only sampling of novel feeds but also reevaluating the quality of known feeds resulting in a comparably high number of eating events. Thus, only partial and no absolute choices for the preferred test feeds were observed (Ginane et al., 2002). The assumption that the animals in the present study expressed sampling behavior is additionally supported by the generally short durations of the eating events $(<0.3$ $\mathrm{min}$ ) with the less preferred test plants. In contrast, eating events on average lasted for $>0.7 \mathrm{~min}$ for the 2 most consumed test plants.

In accordance with Kalio et al.'s (2006) findings, preference ranking based on feeding time was similar to that found for plant intake as correspondingly close correlations were found between feed intake, feeding time, and eating events. This suggests that feeding time for test plants, a variable possibly easier to observe than plant intake, could also be used as indicator of animal preference (Ginane et al., 2002). Even though the general test feed preference ranking was the same for all animals, test plant intake varied considerably between individual animals. For instance, in Exp. 1 A. leucoclada was consumed in a range from 160 to $395 \mathrm{~g} \mathrm{DM} / \mathrm{d}$, and similar variations were found in Exp. 2 for feed intake of $B$. pendula. Such variability in individual feed intake was also found by Atwood et al. (2001) under choice feeding conditions and could be an expression of the different nutritional requirements of the individual animals (Kyriazakis and Oldham, 1993). Despite similarities among the animals in terms of breed, age, BW, and performance, they might have differed in morphology and physiology (Provenza et al., 2007).

\section{Conclusion}

Experience with dried low- to medium-quality woody forages did not lead to consistently larger feed or nutrient intake and did not change the feeding behavior of 2 sheep breeds that were offered partly the same and partly different test feeds over $2 \mathrm{wk}$. The sheep seem to have rapidly accepted the novel woody forages provided as dried supplements. Moreover, preference ranking was established during the first days of exposure. However, whether this is the case under different conditions must be tested. The animals in the present study were able to ingest sufficient energy and protein with the basal ration alone, which was offered during the largest part of the day. A choice was provided only during a restricted time period and the animals were never biased by hunger. Choice feeding studies under different conditions will have to show whether experience is more important for fresh woody forages offered on rangelands compared to feeding of dried forages as supplements.

\section{LITERATURE CITED}

Abbeddou, S., S. Rihawi, H. D. Hess, L. Iñiguez, A. C. Mayer, and M. Kreuzer. 2011. Nutritional composition of lentil straw, vetch hay, olive leaves, and saltbush leaves and their digestibility as measured in fat-tailed sheep. Small Rumin. Res. 96:126-135.

Agricultural and Food Research Council (AFRC). 1993. Energy and protein requirements of ruminants. $\mathrm{CAB}$ International, Wallingford, UK.

Ahn, J. H., B. M. Robertson, R. Elliott, R. C. Gutteridge, and C. W. Ford. 1989. Quality assessment of tropical browse legumes: Tannin content and protein degradation. Anim. Feed Sci. Technol. 27:147-156.

AOAC. 1997. Official methods of analysis. 16th ed. AOAC Int., Gaithersburg, MD.

AOAC. 2000. Official methods of analysis. 17th ed. AOAC Int., Gaithersburg, MD. 
Arbeitsgemeinschaft Deutscher Rinderzüchter (ADR). 2002. ADREmpfehlung 1.10 zur infrarotanalytischen Untersuchung von Schaf- und Ziegenmilch mit dem MilkoScan. (In German.) Arbeitsgemeinschaft Deutscher Rinderzüchter e. V., Bonn, Germany.

Atwood, S. B., F. D. Provenza, R. D. Wiedmeier, and R. E. Banner. 2001. Influence of free-choice vs. mixed-ration diets on food intake and performance of fattening calves. J. Anim. Sci. 79:3034-3040.

Ben Salem, H., A. Nefzaoui, H. P. S. Makkar, H. Hochlef, I. Ben Salem, and L. Ben Salem. 2005. Effect of early experience and adaptation period on voluntary intake, digestion, and growth in Barbarine lambs given tannin-containing (Acacia cyanophylla Lindl. foliage) or tannin-free (oaten hay) diets. Anim. Feed Sci. Technol. 122:59-77.

Bryant, J. P., F. D. Provenza, J. Pastor, P. B. Reichardt, T. P. Clausen, and J. T. du Toit. 1991. Interactions between woody plants and browsing mammals mediated by secondary metabolites. Annu. Rev. Ecol. Syst. 22:431-446.

Capper, B. S., E. F. Thomson, S. Rihawi, A. Termanini, and R. Macrae. 1986. The feeding value of straw from different genotypes of barley when given to Awassi sheep. Anim. Prod. 42:337-342.

Catanese, F., R. A. Distel, F. D. Provenza, and J. J. Villalba. 2012. Early experience with diverse foods increases intake of nonfamiliar flavors and feeds in sheep. J. Anim. Sci. 90:2763-2773.

Catanese, F., R. A. Distel, R. M. Rodríguez Iglesias, and J. J. Villalba. 2010. Role of early experience in the development of preference for low-quality food in sheep. Animal 4:784-791.

Distel, R. A., J. J. Villalba, H. E. Laborde, and M. A. Burgos. 1996. Persistence of the effects of early experience on consumption of low-quality roughage by sheep. J. Anim. Sci. 74:965-968.

du Toit, J. T., F. D. Provenza, and A. Nastis. 1991. Conditioned taste aversions: How sick must a ruminant get before it learns about toxicity in foods? Appl. Anim. Behav. Sci. 30:35-46.

Duncan, A. J., C. Ginane, I. J. Gordon, and E. R. Ørskov. 2003. Why do herbivores select mixed diets? In: L. 't Mannetje, L. RamírezAvilés, C. Sandoval-Castro, and J. C. Ku-Vera, editors, Matching herbivore nutrition to ecosystems biodiversity. Proc. 6th Int. Symp. Nutrition of Herbivores, Universidad Autónoma de Yucatán, Mérida, Yucatán, Mexico. p. 195-209.

Flores, E. R., F. D. Provenza, and D. F. Balph. 1989. The effect of experience on the foraging skill of lambs: Importance of plant form. Appl. Anim. Behav. Sci. 23:285-291.

Forbes, J. M. 2007. Voluntary food intake and diet selection in farm animals. 2nd ed. CAB Int., Wallingford, UK.

Ganskopp, D., and R. Cruz. 1999. Selective differences between naive and experienced cattle foraging among eight grasses. Appl. Anim. Behav. Sci. 62:293-303.

Ginane, C., R. Baumont, J. Lassalas, and M. Petit. 2002. Feeding behaviour and intake of heifers fed on hays of various quality, offered alone or in a choice situation. Anim. Res. 51:177-188.

Kaitho, R. J., N. N. Umunna, I. V. Nsahlai, S. Tamminga, J. van Bruchem, J. Hanson, and M. van de Wouw. 1996. Palatability of multipurpose tree species: Effect of species and length of study on intake and relative palatability by sheep. Agrofor. Syst. 33:249-261.

Kalio, G. A., U. I. Oji, and A. Larbi. 2006. Preference and palatability of indigenous and exotic acid soil-tolerant multipurpose trees and shrubs by West African Dwarf sheep. Agrofor. Syst. 67:123-128.

Kyriazakis, I., and J. D. Oldham. 1993. Diet selection in sheep: The ability of growing lambs to select a diet that meets their crude protein $($ nitrogen $\times 6.25$ ) requirements. Br. J. Nutr. 69:617-629.
Leng, R. A. 1997. Tree foliage in ruminant nutrition. FAO Animal Production and Health Paper 139. FAO, Rome, Italy.

Makkar, H. P. S. 2003. Quantification of tannins in tree and shrub foliage. A laboratory manual. Kluwer Academic Publishers, Dordrecht, The Netherlands.

Meier, J. S., M. Kreuzer, and S. Marquardt. 2012. Design and methodology of choice feeding experiments with ruminant livestock. Appl. Anim. Behav. Sci. 140:105-120.

Murad, N. 2000. A study on the Syrian steppe and forage shrubs. In: G. Gintzburger, M. Bounejmate, and A. Nefzaoui, editors, Fodder shrub development in arid and semi-arid zones. Proc. of the Workshop on Native and Exotic Fodder Shrubs in Arid and Semi-Arid Zones. Vol. I. International Center for Agricultural Research in the Dry Areas, Aleppo, Syria. p. 109-121.

Nolte, D. L., and F. D. Provenza. 1992. Food preferences in lambs after exposure to flavors in solid foods. Appl. Anim. Behav. Sci. 32:337347.

Oh, J. H., I. D. Hume, and D. T. Torell. 1972. Development of microbial activity in the alimentary tract of lambs. J. Anim. Sci. 35:450-459.

Ortega-Reyes, L., and F. D. Provenza. 1993. Amount of experience and age affect the development of foraging skills of goats browsing blackbrush (Coleogyne ramosissima). Appl. Anim. Behav. Sci. 36:169-183.

Pereira, J. A., I. Oliveira, A. Sousa, P. Valentão, P. B. Andrade, I. C. F. R. Ferreira, F. Ferreres, A. Bento, R. Seabra, and L. Estevinho. 2007. Walnut (Juglans regia L.) leaves: Phenolic compounds, antibacterial activity and antioxidant potential of different cultivars. Food Chem. Toxicol. 45:2287-2295.

Provenza, F. D., and D. F. Balph. 1988. Development of dietary choice in livestock on rangelands and its implications for management. J. Anim. Sci. 66:2356-2368.

Provenza, F. D., J. A. Pfister, and C. D. Cheney. 1992. Mechanisms of learning in diet selection with reference to phytotoxicosis in herbivores. J. Range Manage. 45:36-45.

Provenza, F. D., J. J. Villalba, J. Haskell, J. W. MacAdam, T. C. Griggs, and R. D. Wiedmeier. 2007. The value to herbivores of plant physical and chemical diversity in time and space. Crop Sci. 47:382-398.

Shipley, L. A., S. Blomquist, and K. Danell. 1998. Diet choices made by free-ranging moose in northern Sweden in relation to plant distribution, chemistry, and morphology. Can. J. Zool. 76:1722-1733.

Tadros, K. 2000. Fodder shrubs in Jordan. In: G. Gintzburger, M. Bounejmate, and A. Nefzaoui, editors, Fodder shrub development in arid and semi-arid zones. Proc. of the Workshop on Native and Exotic Fodder Shrubs in Arid and Semi-Arid Zones. Vol. I. International Center for Agricultural Research in the Dry Areas, Aleppo, Syria. p. 122-133.

Tilley, J. M. A., and R. A. Terry. 1963. A two-stage technique for the in vitro digestion of forage crops. J. Br. Grassl. Soc. 18:104-111.

Van Soest, P. J., J. B. Robertson, and B. A. Lewis. 1991. Methods for dietary fiber, neutral detergent fiber, and nonstarch polysaccharides in relation to animal nutrition. J. Dairy Sci. 74:3583-3597.

Villalba, J. J., F. D. Provenza, and G. Han. 2004. Experience influences diet mixing by herbivores: Implications for plant biochemical diversity. Oikos 107:100-109.

Yashphe, J., I. Feuerstein, S. Barel, and R. Segal. 1987. The antibacterial and antispasmodic activity of Artemisia herba alba Asso. II. Examination of essential oils from various chemotypes. Int. J. Crude Drug Res. 25:89-96. 